\title{
Kedudukan dan Fungsi Komisi Yudisial Republik Indonesia
}

\author{
Jawahir Thontowi \\ Fakultas Hukum Universitas Islam Indonesia \\ Jl. Tamansiswa No. 158 Yogyakarta \\ impress_jawahir@yahoo.com
}

\begin{abstract}
This article sum up that Judicial Commission (JC) in Indonesia has a strong position in the constitution, UUD 1945 (after amendment). Its JC's position is legally considered a similar position with The Supreme Court and Constitutional Court. In practice, however, its JC's function is less effective to be an external control against judges code of conduct.

Three factors are involved to make the JC fails to establish control effectively. One is the decreasing integrity of the JC due to the fact that The Deputy of Chief was involved in bribery practice. Second, the weakness of leadership which set a side of the JC's core business, as an external control. The third, The Constitutional Court is decision led the JC's function to undermine its authority. In order to improve its effective control, it is necessary to attempt certain efforts. On the one hand, the $\mathrm{JC}$ is demanding not only to maintain its personal integrity, but also need to change a leadership system. More importantly, the $\mathrm{JC}$ capability to join collaboration in supporting government and legislative member in revising the bill No 24/2002 need to take into account.
\end{abstract}

Key words : Judicial commission, judges code of conduct, and supreme court.

\begin{abstract}
Abstrak
Artikel ini menyimpulkan bahwa Komisi Yudisial di Indonesia memiliki posisi yang kuat dalam undangundang, UUD 1945 (setelah amandemen). Posisi Komisi Yudisial secara hukum dianggap sama dengan Mahkamah Agung dan Pengadilan Konstitusi. Meskipun, dalam prakteknya, fungsi Komisi Yudisial kurang efektif untuk menjadi kontrol eksternal kode etik para hakim.

Tiga faktor yang berperan untuk menyebabkan Komisi Yudisial gagal untuk menciptakan kontrol secara efektif. Pertama adalah berkurangnya integritas dari Komisi Yudisial berdasarkan fakta yang menunjukkan bahwa Wakil Ketua telah terlibat dalam praktek penyuapan. Kedua, kelemahan kepemimpinan yang ditetapkan di samping kepentingan inti komisi yudisial, sebagai kontrol eksternal. Ketiga, Pengadilan Konstitusi adalah keputusan yang memimpin fungsi Komisi Yudisial untuk mengacaukan otoritasnya. Untuk meningkatkan kontrol yang efektif, diperlukan untuk mencoba upaya khusus. Di sisi lain, Komisi Yudisial meminta tidak hanya untuk menjaga integritas individu, tapi juga diperlukan untuk mengubah sistem kepemimpinan. Lebih penting lagi, kemampuan Komisi Yudisial untuk menggabungkan kolaborasi dalam mendukung anggota pemerintah dan legislative dalam memperbaiki UU No. 24/2002 perlu dipertimbangkan.
\end{abstract}

Kata kunci : Komisi yudisial, kode etik hakim, dan mahkamah agung. 


\section{Pendahuluan}

Kiprah Komisi Yudisial (KY) sejak dibentuk pada 2005 hingga kini tidak sebanding dengan misi suci yang diembannya. Upaya memperjuangkan negeri ini agar terbebas dari korupsi, kolusi, nepotisme (KKN) dengan cara mengawasi kode etik dan perilaku hakim-hakim yang masih belum tercapai. Praktik mafia peradilan terjadi karena tidak ada sistem pengawasan terpadu dan handal. Tidak dapat disanggah, secara konstitusional posisi KY sangat dipercaya. Kehadiran KY penting bukan saja dalam rangka memerangi bahaya laten korupsi yang melibatkan oknumoknum di lembaga peradilan, namun juga mencetak hakim-hakim yang bermartabat dan menjunjung tinggi etika.

Kemunculan sejumlah kasus yang mengindikasikan praktik mafia peradilan yang melibatkan oknum hakim membawa pertanyaan "mengapa pengawasan terhadap hakim-hakim perlu dilakukan oleh KY? Pertama, pembentukan KY adalah amanah konstitusional UUD 1945, yang merupakan hukum tertinggi dalam hirarki sistem peraturan perundang-undangan (constitusion is the supreme law of the land). ${ }^{1}$ KY selain sebagai lembaga negara yang memiliki fungsi dan kewenangan berkaitan dengan Mahkamah Konsitusi (MK) dan Mahkamah Agung (MA), juga merupakan komisi negara dengan kedudukan yang kuat dalam UUD 1945.

Kedua, kredibilitas KY didasarkan bahwa proses penuangannya dalam UUD 1945 hasil perubahan 1999-2002 merupakan kreasi dan inovasi konstitusional. Harapan pembentukan lembaga negara tersebut untuk meletakkan dasar pemerintahan yang baik dan bersih, termasuk penegakan hukum yang terbuka, handal, berkeadilan, dan penuh pertanggungjawaban.

Ketiga, melimpahnya laporan masyarakat kepada KY, fenomena yang hampir sama dialami oleh MK. Buruknya situasi peradilan di Indonesia, tidak sekadar karena faktor mentalitas aparat peradilan, juga karena sistem peradilan yang mudah diintervensi oleh pemegang kekuasaan. Dalam beberapa tahun saja, KY telah menerima 7.450 laporan dari masyarakat mengenai proses peradilan yang janggal dan terindikasi melanggar hukum, sebanyak 2.567 laporan telah ditindaklanjuti. ${ }^{2}$ Persoalan ini sangat menentukan menjadi bahan pertimbangan dalam kepemimpinan mendatang.

\footnotetext{
${ }^{1}$ Pasal 7 UU Nomor 10 Tahun 2004 dengan jelas menyebutkan bahwa urutan peraturan perundang-undangan di Indonesia adalah UUD 1945, UU/Perpu, Peraturan Pemerintah, Keputusan Presiden, dan Peraturan Daerah.

${ }^{2}$ Komisi Yudisial Republik Indonesia, Laporan Komisi Yudisial Republik Indonesia. 2007-2010, Jakarta, Komisi Yudisial, 2010.
} 


\section{Rumusan Masalah}

Berdasarkan latar belakang di atas, maka hasil kajian ini didasarkan pada dua rumusan masalah. Pertama, mengapa peran pengawasan KY belum berimbas positif pada pembentukan hakim-hakim bermartabat? Padahal KY memiliki posisi konstitusional yang sejajar dengan MK dan MA dalam UUD 1945. Kedua, bagaimana upaya mengembalikan peran KY dalam pengawasan perilaku hakim untuk mencetak hakim yang lebih bermartabat di Indonesia?

\section{Tujuan Penelitian}

Studi ini bertujuan memberikan gambaran tentang kedudukan KY dalam UUD 1945 dan hubungannya dengan lembaga negara seperti MA dan MK. Selain itu sebagai upaya untuk mendorong peran KY di masa mendatang dalam menciptakan hakim-hakim bermartabat.

\section{Metode Penelitian}

Studi penelitian dilakukan melalui studi pustaka yang terfokus pada beberapa bahan, baik keterangan hukum yang bersifat primer, maupun keterangan hukum sekunder. Keterangan primer difokuskan pada penelusuran UUD 1945, khususnya Pasal 24, 24 A, 24 B, 24 C. Selanjutnya difokuskan pada Pasal 24 B tentang Komisi Yudisial. Tahap berikutnya dalam penelitian ini adalah fokus pada UU Nomor 22 Tahun 2004 tentang Komisi Yudisial, kemudian dilengkapi upaya melekatkan kewenangan KY yang dicantumkan dalam UU Nomor 3 Tahun 2009 tentang Mahkamah Agung dan UU Nomor 24 Tahun 2003 tentang Mahkamah Konstitusi.

Bahan-bahan sekunder adalah jurnal, majalah, dan buku teori yang relevan dengan pembahasan mengenai revitalisasi KY. Selain itu juga laporan kasus dari KY sendiri, termasuk berbagai informasi dan opini dari artikel surat kabar baik cetak maupun online. Dari hasil pengumpulan data tersebut, lantas menganalisis pasal-pasal UUD 1945 khususnya hubungan antara Pasal 24 A, 24 B, 24 C. Hal ini untuk menjawab seberapa kuatkah posisi konstitusional KY.

Selanjutnya, kajian ini akan menganalisis peran KY berdasarkan UU Nomor 22 Tahun 2004 tentang KY, dikaitkan dengan realitas peran KY dalam melakukan tugas dan kewenangannya. Termasuk, menganalisis faktor penghambat maupun 
mendukung peran KY. Langkah terakhir adalah menganalisis peluang dan tantangan yang saat ini dihadapi KY, termasuk upaya-upaya jangka pendek, jangka menengah, yang harus dilakukan untuk memposisikan peran KY bekerjasama dengan MA.

\section{Hasil dan Pembahasan}

\section{Posisi Konstitusional Komisi Yudisial dalam UUD 1945}

Posisi konstitusional KY dalam UUD 1945 hasil perubahan memiliki legalitas yang sama kuat dengan lembaga-lembaga negara dalam rumpun sistem peradilan. Hal tersebut didasarkan pada tiga argumentasi sebagai berikut: Pertama, legalitas KY didasarkan pada atribut yang intrinsik sebagai lembaga negara dalam suatu rumpun peradilan. Posisi kekuatan berimbang antara KY, MA, dan MK dibuktikan oleh peletakannya dalam UUD 1945 Bab IX yaitu Kekuasaan Kehakiman yang diatur dalam Pasal 24, 24 A, 24 B, dan ayat 24 C. ${ }^{3}$ Meski penyelenggara kehakiman dilakukan oleh MA dan MK, secara implisit keberadaan KY terpayung oleh Pasal 24 ayat (3) yang berbunyi, “Badan-badan lain yang fungsinya berkaitan dengan kekuasaan kehakiman diatur dalam undang-undang."

Kedua, kekuatan konstitusional KY didasarkan pada fakta bahwa ketiga lembaga negara yaitu MA, KY, dan MK berada dalam struktur normatif yang sederajat. Posisi MA diatur dalam Pasal 24 A yang terdiri dari lima ayat. KY diatur dalam Pasal 24 B terdiri dari empat ayat. Sedangkan MK dalam Pasal $24 \mathrm{C}$ yang terdiri dari enam ayat.

Ketiga, kekuatan berimbang antara KY, MA, MK juga didasarkan pada asal-usul semangat zaman pembentukan struktur norma. KY dan MK tidak pernah lahir, kecuali setelah amandemen UUD 1945. Sejak perubahan fase ketiga pada 2001 dengan mengubah dan menambah Pasal 24. Tambahan dalam Pasal 24 menjadi tiga pasal yaitu Pasal 24 A mengenai MA, Pasal 24B mengenai KY, dan Pasal 24 C mengenai MK.

Kehadiran KY diakui sebagai upaya menciptakan fungsi check and balance dalam sistem pengawasan di peradilan. ${ }^{4}$ Kehadiran KY sangat diharapkan karena masyarakat kehilangan kepercayaan pada institusi peradilan. peran pengawasan

\footnotetext{
${ }^{3}$ Undang-Undang Dasar Republik. Indonesia Tahun 1945, Jakarta, PT Armas Duta Jaya, 2002.

${ }^{4}$ Ada sebagian pakar yang tidak setuju meletakkan KY sebagai lembaga negara yang berfungsi menciptakan check and balance, mengingat KY dengan MA dan MK berada dalam satu rumpun. Padahal yang lazim konsep check and balance digunakan untuk lembaga negara yang wewenangnya berbeda sebagaimana halnya lembaga legislatif, eksekutif, dan yudikatif.
} 
internal yang dilakukan MA tidak efektif, karena kerap digunakan sebagai upaya melindungi oknum yang berbuat salah atas nama semangat korps.

Hal ini penting ditegaskan sebagai perwujudan fungsi dan tujuan hukum yaitu upaya memajukan ketertiban dan keadilan. Meskipun Pasal $24 \mathrm{C}$ yang mengatur mengenai MK memiliki enam ayat, lebih banyak daripada Pasal 24 B yang mengatur mengenai KY yang berjumlah empat ayat, bukan berarti KY memiliki derajat konstitusional yang lebih rendah.

Eksistensi konstitusional KY tetap utuh sebagaimana diatur dalam Pasal 24B UUD 1945: 1) Komisi Yudisial bersifat mandiri, yang berwenang mengusulkan pengangkatan hakim agung dan mempunyai wewenang lain dalam rangka menjaga dan menegakkan kehormatan, keluhuran martabat, serta perilaku hakim; 2)Anggota Komisi Yudisial harus mempunyai pengetahuan dan pengalaman di bidang hukum serta memiliki integritas dan kepribadian yang tidak tercela; 3) Anggota Komisi Yudisial diangkat dan diberhentikan oleh presiden dengan persetujuan Dewan Perwakilan Rakyat; 4) Susunan, kedudukan, dan keanggotaan Komisi Yudisial diatur dengan undang-undang.

Melihat posisi konstitusional KY dalam Pasal 24 B UUD 1945 hasil amandemen, maka derajat berimbang antara KY dengan lembaga-lembaga negara serumpun di lingkungan peradilan cukup kuat. Keberadaan KY sebagai lembaga negara diatur dalam UU Nomor 22 Tahun 2004 tentang Komisi Yudisial Pasal 1 ayat (1) yang berbunyi, "Komisi Yudisial adalah lembaga negara sebagaimana dimaksud dalam UUD Negara Republik Indonesia tahun 1945." Sedangkan pada Pasal 2 dijelaskan bahwa "Komisi Yudisial merupakan lembaga negara yang bersifat mandiri dan dalam pelaksanaan wewenangnya bebas dari campur tangan atau pengaruh kekuasaan lainnya". Tugas dan kewenangan KY yang kuat tak akan berdaya jika tidak didukung oleh struktur organisasi dan kepemimpinan yang kokoh.

\section{Struktur dan Kewenangan Komisi Yudisial}

Pemerintah kurang peduli kepada KY sebagai lembaga negara dibandingkan sikap pemerintah terhadap KPK yang berbaju hukum hanya undang-undang saja. Hal ini terbukti dari fakta Presiden terlambat memproses rekrutmen anggota KY yang masa baktinya habis pada Agustus 2010. Sehingga presiden terpaksa mengeluarkan Keputusan Presiden (Keppres) tentang perpanjangan masa bakti. Hal ini sebenarnya bertentangan dengan Pasal 29 UU Nomor 22 Tahun 2004. 
“Anggota KY memegang jabatan selama masa 5 (lima) tahun dan sesudahnya dapat dipilih kembali untuk 1 (satu) kali masa jabatan".

Dalam pengaturan susunan keorganisasian sangat jelas. Pasal 6 ayat (1) menjelaskan, "Komisi Yudisial mempunyai 7 (tujuh) orang anggota", sedangkan pada ayat (2), dijelaskan bahwa anggota KY adalah pejabat negara. Hal ini berkonsekuensi bahwa hak protokoler, keuangan dan tindakan kepolisian untuk anggota KY diberlakukan ketentuan peraturan perundang-undangan bagi pejabat negara sebagaimana dijelaskan pada Pasal 8.

Namun pada tingkat operasional, model kepemimpinan kolegial tidak mampu mendukung tugas utama KY yaitu pengawasan eksternal, yang semestinya dilengkapi dengan struktur kepemimpinan yang meletakkan tanggung jawab yang berada dalam satu komando. Tanpa kode etik kepemimpinan yang tegas mustahil tugas dan kewenangan KY seperti yang diamanahkan Pasal 13 dapat terealisasi dengan baik.

Adapun wewenang dan tugas KY sebagaimana diatur dalam Pasal 13 UU Nomor 22 tahun 2004, sebagai berikut : 1) Mengusulkan pengangkatan hakim agung kepada DPR; 2) Menegakkan kehormatan dan keluhuran martabat serta perilaku hakim. Terkait melaksanakan wewenang pengangkatan hakim agung, KY memiliki tugas sebagai berikut : a. melakukan pendaftaran calon hakim agung. b. melakukan seleksi calon hakim agung. c. menetapkan calon hakim agung. d. mengajukan calon hakim ke DPR.

Salah satu tugas dan kewenangan yang penting adalah menegakkan kehormatan dan menjatuhkan sanksi. Pada Pasal 20 disebutkan, “Dalam melaksanakan wewenang sebagaimana dimaksudkan dalam Pasal 13 huruf b, Komisi Yudisial mempunyai tugas melakukan pengawasan terhadap perilaku hakim dalam rangka menegakkan kehormatan dan keluhuran martabat serta menjaga perilaku hakim."

\section{Kondisi Nyata Komisi Yudisial}

Dibandingkan dengan negara-negara lain, KY di Indonesia memiliki keunikan tersendiri karena merupakan lembaga negara yang mandiri dan terpisah dari MA. Sebab seperti di Amerika Serikat, Australia, Malaysia KY atau Judicial Commission Board merupakan bagian dari institusi MA, hanya saja KY di luar negeri selain memiliki kewenangan pengawasan terhadap hakim MA dan MK juga memiliki kewenangan menyelenggarakan pendidikan dan pelatihan untuk meningkatkan 
kualitas SDM dan perilaku etika hakim-hakim dalam membuat putusan-putusan yang profesional dan berkeadilan. ${ }^{5} \mathrm{KY}$ hingga saat ini masih berjuang mewujudkan visi dan misinya, yaitu menegakkan sistem peradilan yang modern dan bermartabat. Besar harapan agar KY berfungsi dalam menegakkan peradilan yang bermartabat melalui upaya pengawasan eksternal terhadap perilaku hakim.

Antusiasme masyarakat dengan kehadiran KY hampir sama seperti yang dialami Komisi Pemberantasan Korupsi (KPK), yang pendiriannya tidak diatur dalam UUD1945. KPK lahir sebagai perwujudan komitmen politik dan tuntutan rakyat pascareformasi yang mendambakan hilangnya kejahatan korupsi yang berakibat sangat buruk bagi rakyat dan bangsa Indonesia. Sebagaimana dilaporkan, tidak kurang dari 7.450 pelanggaran berasal dari33 provinsi yang masuk dan dikelola. ${ }^{6}$ Meskipun tidak lepas dari kontroversi, KY telah memberikan dampak positif bagi upaya peningkatan kualitas hakim dalam melakukan proses peradilan. Beberapa bukti, hakim-hakim yang dipandang KY menyimpang dari kode etik, termasuk membuat putusan yang tidak semestinya telah memperoleh sanksi hukuman, seperti yang dialami oleh seorang hakim PTUN yang terlibat dalam kasus korupsi Gayus Tambunan. Hal ini adalah bukti nyata fungsi KY mengawasi perilaku hakim untuk menciptakan iklim peradilan yang lebih sehat.

KY tidak luput dari kritik dan kontroversi, berbagai kekurangan masih mendominasi kiprah KY hingga kini. KY perlu memberikan kontribusi yang berarti bagi upaya menegakkan sistem peradilan yang mandiri dan bermartabat. Perlu kiranya mengambil pelajaran dari pengalaman KY negara bagian New South Wales, Australia. Peranan KY di sana sangat diperhitungkan. Hasil kinerja KY telah melenyapkan berbagai kontroversi atas Komisi Yudisial (after two decades, the judicial commission's effective and highly regerded work, has resulted in the disappearance of any controversy, surrounding the establishment). ${ }^{7}$

Persoalan yang tengah dihadapi adalah bagaimana cara agar KY dapat melakukan fungsi pengawasan terhadap hakim-hakim secara efektif sehingga menciptakan sistem peradilan yang mandiri.

${ }^{5}$ Lihat penjelasan lebih lanjut Wikipedia, "Judiciary of Malaysia”, dan "Australia Court Hierarchy", (online), (http://en.wikipedia.org/wiki/Judiciary of Malaysia

http://en.wikipedia.org/wiki/Australian court hierarchy diakses 6 Mei 2010)

"Administrator, 10 Mei 2010, "KY Terima 7.450 Laporan Masyarakat", (online) (http:/ / komisiyudisial.go.id/ index.php?option $=$ com_content\&view $=$ article $\&$ id $=3340 \% 3$ Aky-terima- 7450 -laporan-masyarakat\&catid $=1 \% 3$ ABerita + Terakhir\&Itemid $=295$ \&lang $=$ en $/$ )

${ }^{7}$ Lihat Judicial Commission of New South Wales, 2005, hlm. 10. 


\section{Penurunan Fungsi Komisi Yudisial}

Dalam usianya yang masih tergolong muda, KY mesti menjawab beberapa tantangan. Mengenai persoalan kerangka konstitusional yuridis tentang tugas dan kewenangannya yang terbatas, namun juga tantangan untuk tetap berkiprah maksimal di tengah kuatnya upaya deligitimasi fungsi KY.

\section{Tantangan Yuridis Konstitusional Komisi Yudisial}

Tugas dan kewenangan KY yang terbatas menjadi kelemahan KY sejak awal. Kesan dominan tugas KY terkait dengan kewenangan dalam pengangkatan hakim agung memang terbaca jelas, namun dalam hal kewenangan menjaga dan menegakkan kehormatan, keluhuran martabat serta perilaku hakim telah menimbulkan beragam penafsiran. Multitafsir tersebut timbul terkait dengan kalimat terakhir dalam Pasal 24 B ayat (1), “Komisi Yudisial bersifat mandiri yang berwenang mengusulkan pengangkatan hakim agung dan mempunyai wewenang lain dalam rangka menjaga dan menegakkan kehormatan, keluhuran martabat, serta perilaku hakim".

Setidaknya, kalimat tersebut dapat ditafsirkan sebagai : pertama, semua hakim baik yang ada di jajaran hakim-hakim MA (PN, PT, PA, PAI, PTUN, dan sebagainya), dan juga hakim-hakim agung serta hakim-hakim MK. Tafsir kedua, "serta perilaku hakim" mencakup hakim-hakim termasuk hakim agung yang berada dibawah hirarki MA. Tafsir ketiga, “serta perilaku hakim” mencakup pengawasan KY terhadap hakim-hakim yang tidak termasuk hakim agung dan hakim konstitusi. Seperti yang disampaikan Indriyanto Seno Adji, anggota kuasa hukum 31 orang hakim agung, menyatakan KY hanya memiliki kewenangan mengusulkan pengangkatan hakim dan mengawasinya, namun tidak termasuk hakim agung dan hakim konstitusi. ${ }^{8}$

Beberapa ahli lain menyatakan pendapat yang berbeda, Abdul Gani Abdullah, serta Amir Syamsudin sepakat menyimpulkan bahwa kalimat "perilaku hakim" berlaku bagi hakim di MA dan MK. Seperti yang disampaikan Abdul Gani Abdullah, ketua Badan Pembinaan Hukum Nasional (BPHN) bahwa apa yang tertuang dalam UU Nomor 22 Tahun 2004, yang menempatkan pengawasan KY untuk semua hakim di MA dan juga MK, tidak ada yang diistimewakan dalam UU KY. ${ }^{9}$

Tanpa mempertimbangkan sejarah maksud kelahiran (original intent) Pasal 24 B ayat (1), maka tafsir yang ketiga telah memperlihatkan fungsi efektif KY selama ini.

\footnotetext{
${ }^{8}$ Suara Karya, 12 Mei 2006, "UU Komisi Yudisial Tidak Diskriminatif”, hlm. 4.

${ }^{9}$ Ibid.
} 
Tugas dan kewenangan KY yang minimalis tersebut didukung oleh Jimly Asshiddiqie ketika menganalisis Pasal 24 B ayat (1), terkait dengan status KY sebagai lembaga negara. Jimly mengatakan bahwa fungsi KY menjadi sistem pendukung, artinya fungsi KY dibatasi oleh kewenangan yang tertera dalam UU, tetapi tidak tertera dalam UUD 1945.

Jimly mengatakan bahwa kalimat "mengusulkan pengangkatan hakim agung" dapat dimaknai sebagai kegiatan mengusulkan kepada presiden untuk menerbitkan Keputusan Presiden (Keppres) sebagai tindakan administratif berupa penetapan Keppres yang bersifat beschiking belaka. Tegasnya, kata pengangkatan oleh KY diatur dalam Pasal 13 UU Nomor 22 Tahun 2004, pengusulan bakal calon hakim agung dilakukan oleh KY kepada DPR. Diakui pula oleh Jimly, bahwa ada pendapat yang melihat Pasal 13 UU Nomor 22 Tahun 2004 bertentangan dengan ketentuan Pasal 24 B ayat (1) UUD 1945.

Selain itu, pembatasan kewenangan KY sebagaimana diargumentasikan Jimly juga tidak lepas keberadaan KY sebagai lembaga negara yang bukan lembaga penegak hukum (the enforcer of the rule of law). Lembaga negara yang mempunyai fungsi dan menjalankan fungsi peradilan tertinggi adalah MA dan MK. KY hanya merupakan lembaga penunjang (supporting system) terhadap dan dalam cabang kekuasaan kehakiman. ${ }^{10}$

Pandangan senada juga dikemukakan oleh Susi Dwi Harijanti, aspek kedua yang bisa berkontribusi signifikan atas melemahnya fungsi KY adalah terkait dengan dua hal. Di satu pihak, kehadiran KY dimaksudkan untuk meningkatkan independensi dan akuntabilitas kekuasaan kehakiman dalam sistem yang baru. Konsep KY yang saat itu sedang dirumuskan secara ideal diveto oleh MPR dalam sidang tahunan MPR 2001. ${ }^{11}$ Faktor dominan KY menjadi lemah karena ditempatkan secara kurang tepat dalam struktur ketatanegaran Indonesia, khususnya dalam konteks hubungan antara MA dan KY. Situasi inilah yang mengundang gagasan KY selayaknya digolongkan pada komisi negara.

\section{Pemangkasan Tugas dan Kewenangan KY oleh MK}

Dalam konstelasi ketatanegaraan, lahirnya KY ini juga mengundang guncangan yang cukup berarti. Langkah-langkah kontroversial KY dipandang sebagai ancaman

\footnotetext{
${ }^{10}$ Jimly Asshiddiqie, Perkembangan dan Konsolidasi Lembaga Negara Pascareformasi, Sekretaris Jendral dan Kepaniteraan Mahkamah Konstitusi RI, Jakarta, 2006.

${ }^{11}$ Susi Dwi Harijanti, Kekuasaan Kehakiman yang Merdeka : Timjauan Teori dan Praktik di Indonesia dalam Gagasan Amandemen UUD 1945, Komisi Hukum Nasional, Jakarta, 2008, hlm. 43.
} 
oleh oknum-oknum di lembaga-lembaga peradilan, seperti MA yang masih bernafsu memelihara status quo, akibatnya KY dilawan oleh lembaga yang merasa terancam eksistensinya. Kewenangan KY itupun dipangkas dengan dikabulkannya permohonan uji yudisial UU Nomor 22 Tahun 2004 tentang KY oleh MK. Putusan MK Nomor 005/PUU-IV/2006 tersebut menjadi tragedi buruk bagi keberadaan KY dalam mengemban amanah sucinya. Pemangkasan kewenangan KY oleh MK mengindikasikan adanya pertentangan kepentingan (conflict of interest), sehingga kewenangan KY untuk mengawasi perilaku hakim MA dan MK sirna. Gusliana HB mengidentifikasi hilangnya kewenangan KY karena MK membatalkan delapan pasal. Pembatalan tersebut terkait dengan Pasal 1 angka (5) sepanjang kata-kata hakim konstitusi. Pasal 20, 21, Pasal 22 ayat (1) huruf e, Pasal 22 ayat (5), Pasal 23 ayat (2), (3), (5), Pasal 24 ayat (1), Pasal 25 ayat (3) UU Nomor 22 tahun 2004, dan Pasal 24 ayat (3) UU Nomor 4 tahun 2004 tentang Kekuasaan Kehakiman. ${ }^{12}$

MK mengabulkan permohonan pengujian yudisial Nomor 005/PUU-IV/2006 tertanggal 23 Agustus 2006 atas UU Nomor 22 tahun 2004 tentang Komisi Yudisial. Putusan MK tersebut berdasarkan alasan pertama, belum ada kriteria jelas tentang perilaku hakim sehingga menimbulkan ketidakpastian hukum karena tumpang tindih dengan pengawasan teknis yustisi yang dilakukan oleh pimpinan MA sebagai lembaga pemegang kekuasaan kehakiman. Alasan kedua, pengawasan terhadap hakim yang dilakukan KY adalah pengawasan terhadap individu-individu hakim, bukan terhadap institusi MA. ${ }^{13}$

Adapun keputusan MK yang berdampak melumpuhkan kewenangan KY antara lain sebagai berikut: Pertama, belum adanya kriteria yang jelas tentang penilaian hakim, sehingga menimbulkan ketidakpastian hukum. Adanya timpang tindih kewenangan KY dalam hal pengawasan teknis yustisi yang dilakukan oleh MA, sebagai pemegang kekuasaan kehakiman. Kedua, pengawasan yang dilakukan KY lebih menampakkan pada individu hakim-hakim.

\section{Penggembosan Fungsi KY}

KY menjadi sorotan masyakarat tidak hanya karena persoalan putusan MK, juga karena Irawadi Joenoes, wakil ketua KY tertangkap tangan oleh KPK menerima

\footnotetext{
${ }^{12}$ Gusliana HB, "Komisi Yudisial Kini dan Mendatang Pascaputusan Mahkamah Konstitusi: Antara Harapan dan Kenyataan”, Jurnal Equality, Vol 12 Nomor 2, 2007, hlm. 58.

${ }^{13}$ Mahfud MD., "Rambu Pembatas dan Peluasan Kewenangan Mahkamah Konstitusi”. Makalah disampaikan dalam Seminar Wacana Amandemen Konstitusi, Komisi Hukum Nasional, Jakarta, 12 Juni 2008.
} 
uang suap sebesar Rp. 600.000.000,00 dari rekanan KY dalam pengadaan tanah pada 28 September 2007. Irawadi Joenoes didapati penyidik KPK menerima uang Rp. 600.000.000,00 dan 30.000 dolar AS dari Direktur PT Persada Sembada, Freddy Santoso. Pengadilan Negeri Jakarta akhirnya memutuskan Irawadi Joenoes terbukti bersalah dalam kasus menerima uang suap dan terbukti melakukan kejahatan korupsi yang bertentangan dengan UU Nomor 31 Tahun 1999 tentang Tindak Pidana Korupsi. KY berada dalam posisi tidak menguntungkan berkaitan kasus suap Irawadi Joenoes, hal ini mempengaruhi citra dan kinerja KY.

Upaya yang potensial mengancam sekaligus turut menggembosi peran signifikan KY telah tampak sejak kelahirannya. Pertama, terjadinya pembangkangan atas panggilan pemeriksaan KY terkait kasus suap senilai Rp. 5.000.000.000,00 Harini Wiyoso, salah satu staf MA. Bukti pembangkangan ini dapat dilihat ketika KY yang menurut Pasal 22 ayat (3) mempunyai hak untuk memanggil hakim dan meminta keterangan. Nyatanya Ketua MA Bagir Manan, ketika itu tidak bersedia hadir. ${ }^{14}$

Upaya pelemahan KY itu juga disebabkan sanksi yang dijatuhkan KY sangat tergantung pada hasil Majelis Kehormatan Hakim (MKH). Misalnya jika KY menjatuhkan sanksi kepada hakim-hakim nakal, maka terlebih dahulu sanksi tersebut harus disampaikan kepada pimpinan MA-MK. Kemudian hakim yang sedang bermasalah diberi kesempatan membela diri di hadapan $\mathrm{MKH}$, karena itu dapat dipastikan bahwa hasil rekomendasi KY untuk menghukum hakim yang nakal dapat mudah diabaikan. Hal ini dibuktikan dengan fakta hingga Maret 2008 terdapat sekitar 3.500 pengaduan dan sekitar 27 hakim terkena sanksi, namun tidak satupun rekomendasi KY tersebut ditindaklanjuti MA. ${ }^{15} \mathrm{Hal}$ ini menunjukkan fakta KY tidak mandiri.

Kelemahan KY itulah yang terus menjadi sasaran, misalnya salah satu hakim agung, Djoko Sarwoko mengusulkan pencoretan KY dari Bab IX UUD 1945. Alasannya keberadaan KY dalam lingkup kekuasaan kehakiman mengakibatkan hakim makin tidak independen dalam melaksanakan tugasnya. Menurut salah satu pemberitaan media, ditengarai bahwa ada faktor konspirasi antara para hakim agung dan pengacara yang hendak membubarkan KY.16

${ }^{14}$ Muhammad Atqa, 19 Desember 2005, “KY: Tolak Panggilan, Bagir Intoleran”, (online), (http:// www.detiknews.com/index.php/detik.read/tahun/2005/bulan/12/tgl/19/time/183839/idnews/501957/idkanal/10)

${ }^{15}$ Cristine Tambunan, 9 Februari 2009, "Komisi Yudisial: Urgensi RUU KY”, (online), (http:// christinetambunan.blogspot.com/2009/02/komisi-yudisial-urgensi-ruu-ky.html/)

${ }^{16}$ Arry Anggada, 10 Februari 2006, “Ada Konsiprasi Hakim Agung dan Pengacara Bubarkan KY”, (online), (http:// us.detiknews.com/read/2006/02/10/204723/536923/10/ada-konspirasi-hakim-agung-dan-pengacara-bubarkanky?nd992203605/) 
Upaya melemahkan fungsi KY terlihat dari sikap hakim-hakim yang tidak kooperatif dan abai terhadap putusan atau rekomendasi KY, pengajuan uji materi terhadap UU Nomor 22 Tahun 2004.

\section{Memberdayakan Peran KY}

Kompleksitas problem yang dihadapi KY, memerlukan kerangka kebijakan hukum dan politik yang mendukung lahirnya suatu model pengawasan KY yang lebih handal agar suatu peradilan yang independen dan jujur, serta bermartabat dapat tercipta. Pelaksanaan program yang berdasarkan analisis keunggulan dan peluang dalam skala prioritas jangka pendek dan jangka menengah.

\section{Upaya DPR Merevisi UU Nomor 22 tahun 2004 tentang KY}

Dalam meningkatkan peran sistem peradilan yang mandiri, menjunjung tinggi martabat, serta turut memberantas korupsi dalam proses peradilan, maka kehadiran KY sebagai lembaga negara dalam rumpun peradilan merupakan keniscayaan di negara hukum yang demokratis ini. Hasil penelitian Komite Hukum Nasional (KHN) disimpulkan bahwa pengaturan KY dalam UUD 1945 sudah tepat dan cukup. Kesimpulan ini didasarkan pada kenyataan bahwa pengadilan telah menjadi lembaga yang korup (judicial corruption), pengawasan internal yang dilakukan MA tidak dapat mengendalikan secara maksimal. Untuk itulah KY dibentuk sebagai pengawas eksternal yang preventif dalam bentuk pencalonan hakim agung dan secara represif mempunyai wewenang lain dalam rangka menjaga dan menegakkan kehormatan, keluhuran martabat serta perilaku hakim. ${ }^{17}$

Kedudukan KY secara konstitusional kuat sebagaimana diatur dalam Pasal 24 B, tetapi tidak dapat berfungsi optimal. Kelemahan tersebut dipengaruhi oleh kondisi internal KY dan kondisi eksternal. Kondisi Internal KY terkait kontradiksi antara konstruksi norma dalam UUD 1945 dengan Pasal 13 UU Nomor 22 Tahun 2004 mengenai rumusan obyek terkait dengan yurisdiksi pengawasan KY terhadap para hakim yang kurang jelas. Keterlibatan Wakil Ketua KY, Irawadi Joenoes dalam kasus suap telah menurunkan citra baik KY.

Kondisi eksternal yang mempengaruhi adalah konflik antara KY dan MA. Semula konflik tersebut lebih disebabkan sebagai konsekuensi logis dari

${ }^{17}$ Abdul Fikar Hadjar, "Mekanisme Pengawasan oleh KY”, Makalah disampaikan dalam Seminar Hasil Penelitian KHN, Hotel Milenium, Jakarta, 27 November 2008 
ketidakjelasan objek pengawasan KY yang overlapping dengan fungsi pengawasan yang melekat pada MA. Konflik tersebut tidak terjembatani, sehingga semangat kesatuan korps para hakim di MA menyatu untuk mematahkan peran KY. Bukti konflik tersebut diwujudkan oleh 31 orang hakim agung yang melakukan judicial review ke MK. Pada akhirnya, MK tidak saja memangkas kewenangan pengawasan KY terbatas pada hakim-hakim yang tidak termasuk di dalamnya hakim MA dan MK. Kenyataan lapangan sampai saat ini, beberapa staf penegak hukum dan juga pengacara masih tetap berusaha agar KY ditiadakan dari UUD 1945. Keberadaan KY dinilai telah mempengaruhi kebebasan dan kemandirian hakim dalam membuat putusan.

Keberadaan KY yang baru seumur jagung bila dibandingkan dengan keberadaan MA dan MK, sehingga penguatan peran KY masih panjang. Dalam jangka pendek prioritas program yang harus dilakukan adalah pendekatan politik legislasi dan uji materi Undang-undang Nomor 22 tahun 2004 tentang Komisi Yudisial. Pendekatan politik legislasi adalah program yang mengharuskan KY melakukan lobi dan negosiasi pada pemerintah dan DPR, proaktif memohon dilakukan revisi atas UU Nomor 22 Tahun 2004. Sejumlah pakar Hukum Tata Negara, Jimly Ashiddiqie, Yohannes Usfunan, Harlan M.Fachran, dan Abdul Fikar Hadjar setuju melakukan revisi terhadap UU Nomor 22 Tahun 2004, sehingga tugas dan kewenangan KY dapat kembali kuat dan mempunyai legitimasi dalam pengawasan eksternal terhadap perilaku hakim-hakim. ${ }^{18}$

Begitu pula pemerintah di tingkat pusat dan daerah tidak ketinggalan untuk mendorong dilakukannya revisi UU Nomor 22 Tahun 2004 tersebut. Misalnya, Gubernur Sumatera Selatan, Ir. H. Alex Noerdin mengusulkan agar fungsi KY diperkuat dan tidak terjadi lagi ada hakim yang menolak ketika dipanggil KY. ${ }^{19}$ Mendiskusikan bahan materi RUU serta memasukkan perbaikan-perbaikan dalam RUU tersebut sehingga pengawasan terhadap kinerja dan etika hukum akan lebih efektif dan sesuai dengan semangat reformasi bidang hukum di lembaga peradilan.

Selain itu dilakukan sosialisasi tentang upaya revisi dengan melakukan public hearing antara KY dengan DPR, pemerintah pusat, juga pemerintah daerah.

\footnotetext{
${ }^{18}$ Lihat Pandangan Jimly Asshiddiqie (Sekretaris Lembaga Pengkajian Hukum dan HAM Sinar Z Bismarikum) "Kewenangan Pengawasan Komisi Yudisial", admin on September 26th 2008. Hal 3 Harlan M.Fachran. Konsultan Nasional Gerakan Anti Korupsi. Kertas kerja "Urgensi Perubahan atas UU Nomor 22 tabun 2004 tentang Komisi Yudisial” disampaikan dalam seminar Upaya Mendorong Kesinambungan Proses Reformasi Peradilan Demi Terwujudnya Sistem Peradilan yang Bersih, Akuntabel, dan Berwibawa, UNPAD Bandung, 18 Januari 2007.

19 Sriwijaya Post, 27 Mei 2010, "Fungsi Komisi Yudisial perlu Diperkuat", (online), (http:// palembang.tribunnews.com/view/36515/fungsi_komisi_yudisial_perlu_diperkuat/)
} 
Meskipun KY menyesalkan fakta bahwa DPR tidak memasukkan revisi UU KY dalam program legislasi nasional, Ketua dan Wakil Ketua KY terus menggelindingkan usulan revisi UU KY pada DPR dan pemerintah. Awal tahun 2010, Busyro Muqoddas meminta Presiden Susilo Bambang Yudhoyono dan DPR serius dalam membuat RUU Komisi Yudisial sebagai revisi dari UU Nomor 22 Tahun 2004 tentang KY. Usulan revisi itu penting untuk memperkuat kewenangan KY dalam memberantas mafia peradilan. Secara khusus KY telah menyampaikan hal tersebut pada Presiden SBY pada pertemuan dengan ketua-ketua Lembaga Negara. ${ }^{20}$ Selain itu juga meningkatkan kerjasama antara Satgas Mafia Hukum dengan KY.21

Peluang KY untuk bekerjasama dengan DPR RI merevisi UU harus dilakukan optimal mengingat kemauan politik pemerintah maupun DPR tampaknya sama melakukan politik penyanderaan. Selain itu kepercayaan masyarakat terhadap KY terus meningkat dari tahun ke tahun. Menurut laporan KY pada 2009 dicatat bahwa jumlah surat laporan pengaduan kepada KY terus meningkat signifikan. Peningkatan laporan dicatat sejumlah 388 laporan pada 2005, 2006 menjadi 1.401 laporan, 1.513 laporan pada 2007, tahun 2008 ada 1.656 laporan, dan 2.104 laporan pada $2009 .^{22}$

Meskipun jumlah laporan mengindikasikan meningkat signifikan, tindak lanjut yang dapat dilaksanakan KY sangat terbatas. Misalnya, selama empat tahun (2005 s.d 2009) terdapat 514 kasus, atau sekitar delapan persen dari 7.062 kasus yang dilaporkan. Sebanyak 225 orang hakim yang ditindaklanjuti untuk diperiksa, hanya 45 orang hakim yang direkomendasikan ke MA untuk dikenai sanksi. Terdapat sekitar 16 orang hakim yang memperoleh sanksi yang beraneka ragam dan hanya 5 orang terdiri dari 2 orang (2005 s.d 2008), dan 3 orang (2009) yang diperhentikan dari jabatannya. ${ }^{23}$ Target-target pencapaian yang tergambarkan di atas memang belum memenuhi harapan masyarakat, sehingga kerja keras KY masih sangat dibutuhkan.

${ }^{20}$ Administrator, 10 Januari 2010, 'Perluasan Kewenangan KY Dukung Pemberantasan Korupsi, ”(online), (http:/ /www.waspada.co.id/index.php/images/index.php?option=com_content\&view $=$ article\&id=80303:perluasankewenangan-ky-dukung-pemberantasan-korupsi\&catid=59:kriminal-a-hukum\&Itemid=91/)

21 Administrator, 20 April 2010, 'KY-Satgas Bahas Program Pemberantasan Mafia”, (online), (http:// 202.153.129.35/berita/baca/lt4bcd929b6b11c/kysatgas-bahas-program-pemberantasan-mafia-hukum/)

22 Komisi Yudisial Republik Indonesia, 2010, “Laporan Komisi Yudisial Republik Indonesia. Tahunan 2009”, Jakarta: Komisi Yudisial.

${ }^{23}$ Jawahir Thontowi, "Urgensi Hukum dalam UU Nomor 24 Tahun 2004 tentang Mahkamah Konstitusi,” Makalah disajikan dalam rapat Fraksi PAN, DPR RI, Jakarta, 30 Juli 2010. 


\section{Sinkronisasi Tugas dan Kewenangan antara KY dan MA.}

Secara kelembagaan peluang KY untuk memberdayakan perannya dilakukan dengan menjalin hubungan kemitraan dengan MA melalui SKB (Surat Keputusan Bersama) Kode Etik dan Perilaku Hakim antara KY dan MA. Kode etik tersebut dikeluarkan melalui Surat Keterangan (SK) Nomor 1/028/SKB/III/5 Maret 2009. SKB tersebut merupakan terobosan, setidaknya objek pengawasan nonteknis oleh KY tidak akan tumpang tindih dengan pengawasan teknis oleh MA. ${ }^{24}$

Prioritas program jangka pendek adalah mengajukan uji materi atas UU Nomor 22 Tahun 2004 tentang KY. Peluang ini memang berat mengingat keputusan MK bersifat final, sehingga upaya-upaya hukum telah tertutup. Namun yang perlu diingat bahwa bila upaya hukum tertutup, tidak menutup kemungkinan dilakukan upaya politik. Peluang itu terbuka terutama saat posisi MK saat ini dinilai sebagai lembaga negara superbody. Bukan sekadar karena putusan MK bersifat final sebagaimana diatur oleh Pasal 24 C ayat (1) UUD 1945, tetapi juga karena MK membuat putusan di luar yurisdiksinya. Para ahli hukum tata negara menilai putusan MK Nomor 005/PUU-IV / 2006 tertanggal 23 Agustus 2006 yang dibuat berdasarkan permohonan 31 orang hakim MA merupakan hal yang tragis karena membatasi kewenangan KY, sekaligus menghilangkan fungsi pengawasan KY terhadap hakimhakim MA dan MK. Putusan MK tersebut dipandang melampaui kewenangan (ultra petita) karena pencoretan pengawasan hakim MK dalam UU KY bukan objek yang dimohonkan oleh pemohon. Kecenderungan UU MK untuk direvisi jelas telah teragendakan dalam Program Legislasi Nasional (Prolegnas) di DPR RI pada 2010.

Penulis dalam kesempatan seminar tersebut menegaskan bahwa untuk mencegah MK yang superbody dan tetap berfungsi sebagai pelindung UUD maka sifat putusan yang final tidak diberlakukan secara absolut. Meskipun kata putusan MK final adalah amanah UUD 1945, namun jika hakikat pasal tersebut mendorong kematian norma universal (the dead constitution), maka terobosan progresif oleh hakim sangat diperlukan manakala ruang keadilan dalam hukum yang hidup (living law) tersedia. Dalam keadaan tertentu, celah putusan MK yang dibuat oleh hakim-hakim yang kemampuannya sangat terbatas, sebagaimana pembuat UU yang telah diuji bukan sesuatu yang mustahil. Jika saja putusan itu, dalam suatu waktu dan keadaan

${ }^{24}$ Administrator, 8 April 2009, “SKB MA-KY Tentang Kode Etik dan Perilaku Hukum,” (online), (http:// www.politikindonesia.com/index.php? k=hukum \&i=1148-SKB\%20MA-KY\%20tentang\%20 Kode\%20Etik\%20dan\%20Perilaku\%20Hakim/) 
tertentu dipandang tepat (belum tentu benar) oleh kehendak masyarakat maka semangat UUD yang hidup (living contitution) harus menerima adanya usulan melakukan uji materi. Hanya saja, batas waktu bekerja uji materi harus dianalogikan dengan sifat UU Kearsipan yang mengandung informasi kerahasian negara yaitu 25 tahun boleh dibuka untuk kepentingan publik. ${ }^{25}$

Senada dengan itu, Irman Putrasidin, menegaskan bahwa perilaku hakim konstitusi wajib diawasi untuk menjaga agar martabat institusi MK tetap pada tempatnya, karena itu KY mulai berpeluang untuk menguji kembali materi pasal pengawasan hakim konsititusi yang sempat ditolak dalam putusan MK Nomor 005/ PUU-IV/2006. Kalau KY cerdas, maka hal tersebut akan diajukan sekarang, siapa tahu putusan berubah. Itu pernah terjadi saat putusan MK dalam mengadili calon independen. Pada 2003 itu pernah diajukan tapi ditolak, namun diterima pada 2008. Kekeliruan itu pasti ada, itu lumrah. Hari ini konstitusional, besok ditemukan fakta baru bahwa putusan itu tidak konstitusional. Kalau pencari keadilan tidak puas, itu bisa diajukan kembali, karena ada asas hakim tidak boleh menolak perkara. ${ }^{26}$ Peluang untuk melakukan uji materiil atas hasil putusan MK, mestinya dalam waktu tertentu harus ada peluang untuk melakukan uji materiil putusan tersebut.

\section{Penutup}

Keberadaan KY secara konstitusional sangat lejitimit karena berada satu rumah dengan institusi peradilan dengan jaminan pasal 24B UUD 1945. Namun pada tingkat implementasi, KY dihadapkan pada tantangan internal dan eksternal. Tantangan internal yang dihadapi KY adalah ambivalensi pengaturan tentang KY dalam UUD 1945 dan struktur organisasi dan model kepemimpinan yang bersifat kolegial. Fokus program pengawasan tidak dapat dilakukan dengan mandiri, selain itu integritas KY menjadi kurang dipercaya masyarakat. Hal ini terjadi saat wakil ketua KY, Irawadi Joenoes tersangkut kasus suap. Tantangan eksternal adalah keputusan MK yang membatalkan tugas dan kewenangan KY dalam mengawasi hakim agung dan hakim konstitusi, hal ini berakibat peran KY sebagai pengawas eksternal menjadi jauh dari harapan. Kedua tantangan itu berpengaruh pada fungsi KY yang kini

\footnotetext{
25 Jawahir Thontowi, Loc. Cit.

26 Administrator, 22 Juli 2010, "KY Berpeluang Ujikan Kembali Pasal Pengawasan Hakim Konstitusi," (online), (http:/ / komisiyudisial.go.id/index.php?option=com_content\&view $=$ article\&id $=3495 \% 3 \mathrm{~A}$-ky-berpeluangujikan-kembali-pasal-pengawasan-hakim-konstitusi\&catid=1\%3ABerita+Terakhir\&Itemid=295\&lang=en/)
} 
timpang, karena fungsi pengawasan KY yang semakin terbatas pada hakim di luar hakim MA dan MK.

Untuk meningkatkan peran KY tersebut diperlukan prioritas program yang dijadikan acuan jangka pendek. Revisi UU Nomor 22 Tahun 2004 kepada pemerintah dan DPR sebagai dasar kebijakan KY untuk melakukan lobi efektif. Penambahan tugas dan kewenangan KY yang lebih mandiri dalam melakukan pengawasan tidak sekedar turut hadir dalam pemeriksaan di Majelis Kehormatan Hakim (MKH). Secara internal, perubahan struktur organisasi dan kepemimpinan yang memiliki dorongan moral dan efek yang menempatkan tanggung jawab pada seorang ketua terhadap wewenang pokok pengawasan mutlak harus dilakukan. Kedua program ini dipandang menjanjikan mengingat kedudukan konstitusionalitas KY dalam UUD 1945, serta kepercayaan masyarakat terhadap KY cukup tinggi.

\section{Daftar Pustaka}

Asshiddiqie, Jimly, Perkembangan dan Konsolidasi Lembaga Negara Pascareformasi, Sekretaris Jenderal dan Kepaniteraan Mahkamah Konstitusi RI, Jakarta, 2006. Kewenangan Pengawasan Komisi Yudisial, Sekretaris Lembaga Pengkajian Hukum dan HAM, Jakarta, 2008.

Fachran, Harlan M, Urgensi Perubahan Atas UU Nomor 22 Tahun 2004 Tentang Komisi Yudisial, Makalah seminar Upaya Mendorong Kesinambungan Proses Reformasi Peradilan Demi Terwujudnya Sistem Peradilan yang Bersih, Akuntabel dan Berwibawa, Bandung, 18 Januari 2007.

Hadjar, Abdul Fikar, Mekanisme Pengawasan oleh KY, Makalah seminar Hasil Penelitian KHN, Komisi Hukum Nasional, Jakarta, 27 November 2008.

Harijanti, Susi Dwi, Kekuasaan Kehakiman yang Merdeka : Tinjauan Teori dan Praktik di Indonesia dalam Gagasan Amandemen UUD 1945, Komisi Hukum Nasional, 2008.

HB, Gusliana, "Komisi Yudisial Kini dan Mendatang Pascaputusan Mahkamah Konstitusi: Antara Harapan dan Kenyataan", Jurnal Equality, Volume 12, Nomor 2, 2007.

Judicial Commission of New South Wales, 2005.

Komisi Yudisial Republik Indonesia, "Laporan Komisi Yudisial Republik Indonesia. Tahunan 2009", Jakarta, 2010.

MD, Mahfud, Rambu Pembatas dan Peluasan Kewenangan Mahkamah Konstitusi, Makalah seminar Wacana Amandemen Konstitusi, Komisi Hukum Nasional, Jakarta, 12 Juni 2008.

Thontowi, Jawahir, Urgensi UU No 27 Tahun 2004 Tentang Mahkamah Konstitusi RI. Diskusi Terbatas Fraksi PAN DPR RI. 2010. 
Undang-Undang Dasar Republik Indonesia Tahun 1945

Suara Karya, 12 Mei 2006.

http:/ / 202.153.129.35/berita/baca/lt4bcd929b6b11c/kysatgas-bahas-programpemberantasan-mafia-hukum/

http:/ / www.christinetambunan.blogspot.com/2009/02/komisi-yudisial-urgensiruu-ky.html/

http://www.detiknews.com/index.php/detik.read/tahun/2005/bulan/12/tgl/ 19/time/183839/idnews/501957/idkanal/10

http://en.wikipedia.org/wiki/Judiciary of Malaysia

http://en.wikipedia.org/wiki/Australian_court_hierarchy

http://komisiyudisial.go.id/index.php?option=com content\&view $=$ article\&id $=3340 \% 3 \mathrm{Aky}$-terima-7450-laporan-masyarakat\&catid $=1 \% 3$ ABerita+Terakhir\&Itemid=295\&lang=en/

http: // komisiyudisial.go.id /index.php?option=com content\&view= article\&id $=3495 \% 3 \mathrm{~A}$-ky-berpeluang-ujikan-kembali-pasal-pengawasanhakim-konstitusi\&catid=1\%3ABerita+Terakhir\&Itemid=295\&lang=en /

http://palembang.tribunnews.com/view/36515/fungsi komisi yudisial perlu diperkuat/

http:/ / www.politikindonesia.com/index.php?k=hukum\&i=1148-SKB\%20MAKY\%20tentang\%20Kode\%20Etik\%20dan\%20Perilaku\%20Hakim/

http://us.detiknews.com/read/2006/02/10/204723/536923/10/ada-konspirasihakim-agung-dan-pengacara-bubarkan-ky?nd992203605/

http://www.waspada.co.id/index.php/images/index.php?option=com _content\&view=article\&id=80303:perluasan-kewenangan-ky-dukungpemberantasan-korupsi\&catid=59:kriminal-a-hukum\&Itemid=91/ 